\title{
Pengembangan Alat Permainan Edukatif Kartu Giling Huruf untuk Meningkatkan Kemampuan Membaca Anak Usia Dini 4-6 Tahun
}

\author{
Sri Harti ${ }^{16}$, Nunuk Suryani ${ }^{17}$, Deny Tri Ardianto ${ }^{18}$ \\ srihartititis@yahoo.com
}

\begin{abstract}
Kartu Giling Huruf (KGH) as one of the learning media for reading needs to be developed, both in terms of shape, size, color, and material to be more interesting to children so that children will play this tool more often and more easily understand letters and vocabulary as contained in $\mathrm{KGH}$. This research is intended to develop $\mathrm{KGH}$ as a medium for learning to read for early childhood 4-6 years old. The sampling procedure in this developmental research follows the ADDIE development model (analysis, design, development, implementation, and evaluation) which is carried out in Ar-Rohmah Kindergarten. The stages required observation time along with the development of KGH in semester 2, February - May in 2014/ 2015 academic year. The results of the effectiveness test and trial development results showed that the KGH developed is ready to be used and produced in a wider scope.
\end{abstract}

Keywords: APE, Kartu Giling Huruf, Early Childhood

\footnotetext{
${ }^{16}$ Mahasiswa Magister Teknologi Pendidikan Universitas Sebelas Maret

17 Dosen Magister Teknologi Pendidikan Universitas Sebelas Maret

18 Dosen Magister Teknologi Pendidikan Universitas Sebelas Maret
} 


\section{PENDAHULUAN}

U sia dini merupakan usia bermain yang sekaligus menjadi masa keemasan dan peka bagi anak untuk menerima berbagai stimulasi dan berbagai upaya pendidikan dari lingkungannya (Sujiono \& Sujiono, 2013). Pada usia usia ini, bermain merupakan aktivitas penting karena melalui kegiatan bermain, daya pikir, emosi, sosial, dan fisik anak dapat terangsang dan berkembang. Semakin besar fantasi yang bisa dikembangkan oleh anak dari sebuah mainan, maka akan lebih lama mainan itu menarik bagi si anak. Oleh karena itu, sebelum merancang suatu permainan bagi anak usia dini, pendidik harus paham apa yang menjadi kebutuhan anak sehingga dapat menghasilkan rancangan kegiatan bermain yang menyenangkan dan bermanfaat untuk tumbuh-kembang anak. Dalam kondisi seperti inilah benar-benar dapat dibangun suasana bermain sambil belajar dalam diri anak usia dini. Untuk mewujudkan suasana bermain sambil belajar diperlukan peran pendidik atau pendamping yang dapat merancang permainan yang sesuai dengan perkembangan dan pertumbuhan anak yang hendak dicapai. Oleh karena itu diperlukan strategi yang tepat dalam menangani pembelajaran bagi anak usia dini agar tidak meninggalkan prinsip pendidikan bagi anak usia dini yang menggunakan metode bermain sambil belajar untuk mengoptimalkan semua fungsi kognitif selanjutnya (Sujiono \& Sujiono, 2013).

Salah satu strategi yang cocok digunakan oleh pendidik anak usia dini yaitu mengajar dengan alat permainan edukatif (APE) yang dapat memenuhi berbagai tujuan pembelajaran (Eggen \& Kauchak, 2012). Dalam hal ini permainan dan alat bermain yang dimaksud bukanlah suatu yang harus bernilai ekonomi tinggi, namun dapat menunjang terselenggaranya kegiatan pembelajaran secara efektif dan menyenangkan sehingga dapat mengembangkan berbagai potensi anak secara optimal. APE yang digunakan dalam pembelajaran harus menyesuaikan dengan tujuan pembelajaran dan tema yang disiapkan bagi peserta didik dengan mempertimbangkan kelaziman anak yang belajar karena adanya interaksi dengan orang lain dan keadaan di sekitanya melalui mendengar dan melihat. Ini berarti bahwa identifikasi suatu objek merupakan bagian penting dari proses belajar tersebut, termasuk pengenalan objek berupa huruf. Pemahaman bentuk huruf ini merupakan interaksi anak dengan cara melihat. Sementara pengenalan dan perkembangan kosa kata merupakan interaksi anak dengan cara mendengar. Dari kenyataan ini, bentuk huruf dan perkembangan kosa kata merupakan dua hal penting yang harus dikembangkan pada anak sejak usia dini. Namun demikian, pengembangan dua hal tersebut harus dilakukan dengan cara yang tepat, melalui pembelajaran tematik dan menyesuaikan dengan tumbuh kembang anak.

Melalui bermain sambil belajar menggunakan APE sebagai media diharapkan anak dapat dengan mudah memahami bentuk huruf dan pengucapannya sebagai kata dengan alat permainan yang dia mainkan secara menyenangkan. Selanjutnya, anak akan mampu mengembangkan bahasanya sendiri untuk berlatih membaca. Membaca merupakan bagian sangat penting dari kegiatan mengembangkan kemampuan bahasa anak. Dari membaca anak akan memperoleh pengetahuan, bahkan sering dikatakan bahwa membaca merupakan pintu dan jendela untuk membuka wawasan anak. Oleh karena itu, anak usia dini dengan kemampuan menyerap informasi yang sangat besar perlu mulai diajari membaca dengan cara dan media yang sesuai dan menyenangkan (Hasan, 2009). Lazimnya, pendidikan Taman Kanak-kanak (TK) untuk usia 4-6 tahun tidak ada keharusan bagi peserta didik untuk belajar membaca karena belajar membaca lebih dimaknai sebagai ajang sosialisasi prasekolah. Namun demikian, tidak jarang Sekolah Dasar (SD), terutama SD favorit, mensyaratkan calon peserta didiknya harus sudah bisa membaca. Fakta ini menjadikan banyak TK yang memaksakan peserta didiknya belajar membaca agar bisa diterima di SD favorit setelah lepas dari pendidikan pra sekolah tersebut, walaupun metode dan media yang digunakan cenderung tidak sesuai dengan usia tumbuh kembang anak. Hal ini diperparah lagi dengan ambisi orang tua yang menuntut kemampuan anak untuk segera dapat membaca dengan cara memberikan materi tambahan belajar membaca dengan memanggil guru les atau memasukkan pada lembaga pendidikan non formal yang menyelenggarakan pembelajaran khusus membaca yang jelas-jelas mengabaikan prinsip bermain sambil belajar bagi anak usia dini. 
Maimunah Hasan (2009), berpendapat bahwa mengajarkan membaca pada usia TK tidak salah, namun caranya harus tetap memperhatikan prinsip bermain sambil belajar sehingga anak saat melakukan aktifitas belajar tersebut tetap dalam suasana menyenangkan dan tanpa beban. Pada konteks inilah pendidik dituntut untuk secara cerdas dapat memilih, bahkan membuat media pembelajaran yang berupa APE secara tepat bagi peserta didiknya untuk belajar membaca, sebagaimana yang telah dilakukan oleh para pendidik atau guru di TK Ar-Rohmah Jaten, Karanganyar yang telah membuat APE yang diberi nama Kartu Giling Huruf (KGH) sebagai media untuk mengajari anak membaca secara menyenangkan dalam bentuk permainan. APE ini dirancang sebagai media untuk memudahkan peserta didik belajar membaca dengan mengenali bentuk huruf seperti yang terdapat dalam KGH tersebut. Alat yang diciptakan ini merupakan media pembelajaran yang diharapkan memiliki nilai edukasi tinggi bagi anak usia dini dan sangat mudah digunakan untuk belajar membaca melalui bermain sesuai tema yang sudah ditentukan oleh guru sehingga diharapkan anak mempunyai penguasaan kemampuan membaca lebih cepat dengan cara yang menyenangkan dan merasa tertantang untuk terus belajar membaca.

Anak usia dini akan lebih mudah memahami sesuatu secara langsung melalui melihat, mendengar, dan praktek langsung melalui bermain. Dengan bermain anak mempunyai kemampuan menerima pengetahuan lebih baik karena dalam bermain banyak hal yang anak dapatkan. Oleh karenanya, KGH sebagai salah satu media pembelajaran membaca perlu dikembangkan, baik dari segi bentuk, ukuran, warna, dan bahan agar lebih menarik perhatian anak sehingga anak akan lebih sering memainkan alat ini dan lebih mudah memahami huruf beserta kosa kata seperti yang terdapat dalam KGH. Pada titik inilah dipandang perlu untuk melakukan penelitian pengembangan alat Kartu Giling Huruf tersebut untuk dapat meningkatkan nilai edukasi dan lebih membangkitkan rasa senang anak sehingga anak tertantang untuk terus bermain sambil belajar membaca. Secara detail, penelitian pengembangan KGH ini memiliki tiga tujuan, sebagai berikut.

1. Mengetahui penggunaan Alat Permainan Edukatif/ Media untuk meningkatkan kemampuan membaca di TK Ar-Rohmah Karanganyar.

2. Untuk menghasilkan Alat Permainan Edukatif yang dapat meningkatkan kemampuan membaca anak TK.

3. Untuk mengetahui efektifitas Alat Permainan Edukatif Kartu Giling Huruf (KGH) pada peningkatan kemampuan belajar membaca anak TK.

4. Penelitian pengembangan APE untuk meningkatkan kemampuan membaca bagi anak usia dini ini bukanlah yang pertama dan satu-satunya, namun penelitian ini dimaksudkan untuk memberikan alternatif yang diharapkan dapat melengkapi hasil penelitian-penelitian terdahulu. Misalnya, Kabuto (2009), telah melakukan kajian mendalam tentang pengaruh warna dalam tanda terhadap daya serap siswa dalam menerima materi pembelajaran. Walaupun penelitian pengembangan media pembelajaran ini tidak ditujukan kepada anak usia dini, namun metode yang digunakan dapat diadopsi dan dikembangkan pada pengembangan APE Kartu Giling Huruf. Evangelou, et al. (2010), menunjukkan bahwa lazimnya anak usia dini lebih mudah menerima materi pembelajaran dengan menggunakan media yang teraba atau tertangkap oleh indra untuk memahami suatu objek. Dari pustaka yang berupa jurnal hasil penelitian ini, setidaknya ada beberapa informasi yang dapat dijadikan sebagai data sekunder dari penelitian pengembangan Kartu Giling Huruf.

Wang, Christ, \& Chiu (2014), menunjukkan bahwa pembelajaran untuk pengenalan dan memperkaya perbendaharaan kata bagi anak usia dini diperlukan strategi dan cara yang tepat, baik model dan/atau media pembelajarannya, yaitu model bermain sambil belajar dan media yang sesuai dengan usia tumbuh kembang anak. Membaca menggunakan media merupakan topik yang sama dibahas dalam penelitian yang dilakukan oleh Wang, Christ, dan Chiu maupun penelitian pengembangan $\mathrm{KGH}$, perbedaannya terletak pada tujuan penggunaan $\mathrm{APE}$, dimana dalam penelitian yang dilakukan oleh 
Wang, Christ, dan Chiu bertujuan untuk memperkaya bahasa, tetapi dalam penelitian pengembangan KGH untuk meningkatkan kemampuan membaca. Penelitian pengembangan ini dapat digunakan sebagai alternatif dan pelengkap dari penelitian pengembangan APE untuk meningkatkan kemampuan membaca anak usia dini, sehingga hasil penelitian pengembangan $\mathrm{KGH}$ ini diharapkan dapat digunakan sebagai salah satu solusi untuk memperoleh APE yang tepat untuk meningkatkan kemampuan membaca anak usia dini 4-6 tahun.

\section{METODE PENELITIAN}

Penelitian ini dilakukan pada anak usia 4-6 tahun di TK. Masyithoh dan TK Ar-Rohmah. Penelitian ini dilaksanakan secara bertahap. Waktu pelaksanaan pengamatan beserta pengembangan KGH pada semester 2, bulan Februari - Mei tahun pembelajaran 2014/2015. Penelitian pengembangan KGH ini dirancang dengan menggunakan modifikasi yang dilakukan pada bagian jumlah subjek ujicoba. Pada tahap uji coba ini peneliti melibatkan peserta didik Kelas A TK Masyithoh sebagai ujicoba individu dan ujicoba kelompok kecil yang berjumlah 11 anak. Sementara itu, untuk ujicoba lapangan peneliti melibatkan 49 anak dari TK Ar-Rohmah yang terbagi dalam dua kelas, yaitu kelas eksperimen (Kelompok Cempaka) berjumlah 26 anak, dan kelas kontrol (Kelompok Dahlia), berjumlah 23 anak. tahap.

Model penelitian pengembangan ini mengikuti model desain instruksional ADDIE yang meliputi 5

Pertama, tahap analisis yang meliputi tiga kegiatan, yaitu: 1) studi pustaka yang dilakukan dengan ekplorasi teori dari berbagai pustaka yang relevan untuk memperoleh hasil produk yang baik dan sesuai dengan kebutuhan APE sebagai media belajar membaca bagi anak TK atau anak usia dini usia 4-6 tahun; 2) survey lapangan untuk memperoleh data riil yang ada di lapangan yang berkenaan dengan kegiatan belajar membaca bagi anak usia dini usia 4-6 tahun di TK-A Masyitoh dan TK Ar-Rohmah dengan menggunakan prototipe $\mathrm{KGH}$; dan 3) analis kebutuhan, yaitu kegiatan untuk menyusun draft model pengembangan $\mathrm{KGH}$ yang dilakukan dengan mengacu hasil studi pustaka dan servey lapangan.

Kedua, tahap desain yang terdiri dari dua kegiatan, yaitu: 1) menetapkan kompetensi dasar dan tujuan pembelajaran yang akan dikembangkan dalam kaitannya dengan $\mathrm{KGH}$; dan 2) merancang media pembelajaran berupa KGH yang diharapkan mampu meningkatkan kemampuan membaca anak usia 46 tahun.

Ketiga, tahap pengembangan yang terdiri dari tiga kegiatan berikut.

1) Produk media, pembuatan produk KGH sesuai dengan desain dan rancangan awal.

2) Validasi produk KGH yang terdiri dari dua kegiatan, yaitu: a) validasi ahli media untuk menilai desain KGH yang meliputi bentuk, warna, bahan, kemudahan memainkan dan kesesuaian dengan dunia anak yang dilakukan oleh ahli pengembang kurikulum TK Ar-Rohmah; dan b) validasi ahli materi dilakukan oleh guru senior yang bertugas menilai kelengkapan dan kesesuaian media dengan materi pembelajaran yang sesuai Kompternsi Inti dan Kompetensi Dasar.

3) Ujicoba produk KGH yang terdiri dari tiga kegiatan, yaitu: 1) ujicoba awal (one-to-one trying out) dengan melibatkan 1 - 3 anak; 2) ujicoba kelompok kecil (small group tryout); dan 3) ujicoba kelompok besar atau uji coba lapangan (field tryout) yang sering dikenal dengan istilah uji empiris karena dilakukan untuk menguji validitas produk hipotesis.

Keempat, tahap implementasi /penerapan KGH dalam proses pembelajaran pada kelas eksperimen berguna untuk memperoleh data tentang efektifitas penggunaa $\mathrm{KGH}$ yang kemudian dianalisis dengan menggunakan uji-t. Uji efektifitas ini untuk mengetahui apakah ada perbedaan 
kemampuan membaca antara kelas eksperimen (Kelompok Cempaka) dan kelas kontrol (Kelompok Dahlia).

Kelima, tahap evaluasi yang dilakukan dengan mengevaluasi pada tiap tahapan sesuai langkah pengembangan menggunakan model desain instruksional ADDIE. Hasil evaluasi dipakai sebagai acuan apakah APE KGH sudah tidak memerlukan revisi lagi dan layak untuk digunakan dalam skala luas dan bisa dikatakan produk akhir.

\section{HASIL DAN PEMBAHASAN}

Pengguna dapat melihat secara langsung bentuk KGH dan menggunakannya untuk belajar membaca melalui bermain secara langsung. Sub tema pembelajaran yang akan diajarkan sudah terpasang pada tempat papan kata KGH, sehingga pengguna dalam hal ini peserta didik TK-A dapat berlatih memahami kata yang bisa digiling sesuai sub tema yang sudah terpasang dengan disertai gambar untuk lebih memudahkan anak dalam belajar membaca.

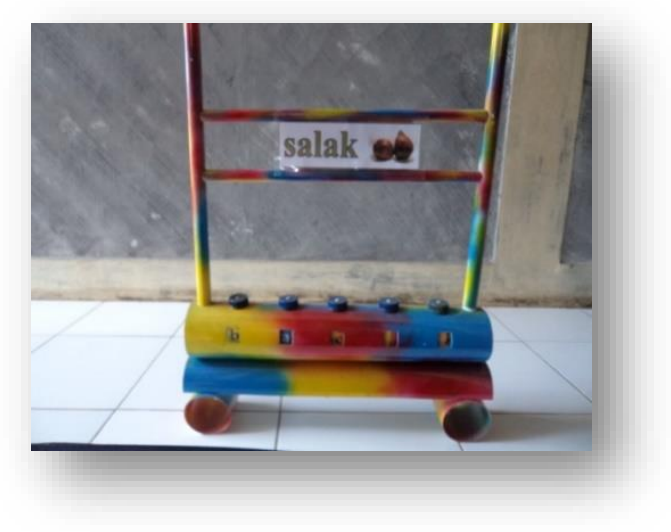

\section{Gambar 1. Tampilan KGH}

Penilaian dalam penelitian pengembangan ini menggunakan penilaian dengan skala 5 kategori, yaitu: sangat tidak baik, tidak baik, cukup baik, baik, sangat baik. Penilaian dari ahli media didapat melalui angket yang diberikan kepada ahli media. Aspek yang dinilai oleh ahli media meliputi: Tampilan dan unsur media yang terbagi dalam 11 indikator. Unsur tampilan ada 8 indikator meliputi: penampilan desain APE, Pemilihan warna huruf, Komposisi ukuran huruf dengan lubang huruf, penempatan huruf pokok/ sub tema, bahan yang digunakan, komposisi warna, kemenarikan, ketepatan kombinasi warna. Unsur media ada 3 indikator meliputi: kemudahan penggunaan, kemudahan memahami huruf , kejelasan gambar dan huruf sub tema. Hasil konvensi penilaian ahli media terhadap tampilan dan unsur media menunjukkan bahwa media APE KGH untuk meningkatkan kemampuan membaca anak TK-A yang dikembangkan berada pada kategori baik dengan skor rata-rata 4.

Validasi dari ahli materi dilakukan di ruang sentra persiapan yang merupakan ruang untuk menempatkan alat-alat permainan bagi anak di TK Ar-Rohmah untuk belajar membaca, menulis, dan berhitung. Ahli materi menggunakan produk KGH didampingi oleh pengembang, sehingga ahli materi dapat menanyakan langsung hal-hal yang berkaitan dengan produk yang dikembangkan, serta langsung dapat memberikan masukan berupa kritik dan saran kepada pengembang yang digunakan sebagai pedoman untuk melakukan perbaikan terhadap produk KGH yang dikembangkan.

Ahli materi menilai dari Aspek isi dan fungsi media. Aspek isi meliputi 5 indikator, yaitu: kesesuaian alat dengan tujuan pembelajaran, materi sesui dengan kompetensi inti, materi sesuai dengan kompetensi dasar, kedalaman materi yang disajikan, serta kemudahan memahami materi. Aspek fungsi ada 5 
indikator, yaitu: penggunaan dengan cara sederhana dan mudah, dapat mengembangkan berbagai aspek kecerdasan, meperhatikan segi keamanan, menjadikan anak aktif serta sifatnya konstruktif. Dari penilaian yang dilakukan oleh dua orang ahli materi diperoleh jumlah skor 49 dari ahli materi I, sedangkan dari ahli materi II diperoleh jumlah skor 48. Hasil konvensi pada data yang divalidasi oleh kedua ahli materi menunjukkan bahwa APE KGH yang dikembangkan memiliki kategori sangat baik dengan skor rata-rata 4,85. Hasil konvensi dari hasil uji coba individu dan kelompok kecil serta ujicoba lapangan meliputi 3 aspek, yaitu tampilan terdiri dari 6 indikator: bentuk fisik menarik perhatian anak, menimbulkan keinginan anak untuk bermain, memungkinkan anak betah bermain (5-20 menit), tampilan huruf dan gambar, sub tema mudah dipahami, dan warna menarik perhatian anak .Aspek penyajian materi meliputi 3 kategori, yaitu: materi sesuai tema dan sub tema pembelajaran, penggunaan sangat mudah, kejelasan petunjuk pemakaian yang dijelaskan oleh guru dan kemudahan pemahaman untuk menyampaikan materi sesuai sub tema. Aspek pemanfaatan meliputi satu indikator, yaitu memudahkan anak untuk belajar membaca melalui bermain. Hasil konvensi penilaian 11 indikator yang ada dalam uji coba individu dan kelompok kecil menunjukkan bahwa media KGH yang dikembangkan memiliki kategori baik dengan total skor rata-rata 40.35. Sementara itu, Uji coba lapangan (field tryout) yang dilakukan pada TK-A TK ArRohmah di kelompok Cempaka sebagai kelas eksperimen dengan jumlah peserta didik 26 anak menunjukkan bahwa nilai kemampuan anak membaca sebelum menggunakan APE KGH mempunyai skor rata-rata 30 dan setelah belajar membaca menggunakan $\mathrm{KGH}$ nilai rata-rata menjadi 41,92. Dari hal tersebut dapat disimpulkan bahwa ada peningkatan kemampuan membaca setelah peserta didik berlatih membaca menggunakan $\mathrm{KGH}$.

Dari Uji efektifitas penggunaan APE KGH dengan uji-t didapatkan nilai rata-rata kelas eksperimen adalah 41,92, sementara itu kelas kontrol hanya mendapat nilai rata-rata 30,91 karena tidak menggunakan APE KGH dan hanya menggunakan huruf yang ditebali ketika belajar membaca. Dapat disimpulkan bahwa penggunaan APE KGH dalam ujicoba lapangan sanagat efektif dan sudah memenuhi kategori sangat baik dan layak digunakan dalam upaya meningkatkan kemampuan membaca anak TKA di TK Ar-Rohmah, Jaten, Karanganyar.

\section{SIMPULAN DAN SARAN}

Berdasarkan hasil penelitian pengembangan $\mathrm{KGH}$ yang dilakukan, dapat ditarik tiga simpulan sebagai berikut.

1. KGH sebagai salah satu media pembelajaran membaca sangat cocok dan menarik bagi anak usia dini, baik dari segi bentuk, ukuran, warna, dan bahan merangsang anak untuk lebih sering memainkan alat ini sehingga anak lebih mudah memahami huruf dan kosa kata seperti yang terdapat dalam KGH.

2. Penelitian pengembangan ini dilakukan melalui beberapa tahapan sesuai prosedur tahap penelitian pengembangan yang terdiri dari 5 tahap, yaitu: a) penelitian pendahuluan yang meliputi identifikasi kebutuhan pembelajaran; b) pembuatan desain APE KGH yang meliputi kompetensi inti dan kompetensi dasar serta tujuan pembelajaran, perumusan materi, penulisan indikator, dan pengembangan materi pembelajaran; c) pengembangan produk yang meliputi pembuatan APE dan melakukan validasi ahli media dan ahli materi; d) implementasi APE KGH dalam proses belajar membaca pada kelas eksperimen; dan e) tahap evaluasi yang dilakukan untuk mengevaluasi KGH yang sudah dikembangkan dan diujicobakan untuk menuju produk final.

3. Hasil data validasi dari ahli materi I diperoleh rata-rata 4.9 dan dari ahli materi II diperoleh ratarata 4.8, sedangkan dari ahli media diperoleh rata-rata 4. Hasil ujicoba tahapan individu (one-toone trying out) dan uji coba kelompok kecil (small group tryout) diperoleh rata-rata 40,35, artinya APE KGH sudah masuk kategori sangat baik. Dari tahapan uji coba kelompok besar (field tryout) 
diperoleh total nilai rata-rata 41,92 setelah menggunakan APE KGH lebih besar daripada sebelum menggunakan APE KGH yang total nilai rata-ratanya hanya 30 . berikut.

Saran yang dapat disampaikan berdasarkan penelitian ini terutama bagi TK Ar-Rohmah sebagai

1. Bagi peserta didik, hendaknya dengan adanya KGH dapat belajar membaca dengan mudah dan cepat serta dapat memahami materi pembelajaran yang disampaikan pendidik dengan baik karena dalam KGH materi yang disampaikan sudah ada gambar yang tertera dan peserta didik dapat berdiskusi lebih banyak dengan pendidik tentang tema pembelajaran yang sedang dibahas lebih luas.

2. Bagi pendidik, mengingat anak dapat belajar efektif jika pembelajaran yang disampaikan sesuai dengan dunianya, yaitu belajar melalui bermain, maka pendidik harus kreatif menggunakan KGH untuk membahas materi atau tema pembelajaran yang lebih luas.

3. Bagi sekolah, penggunaan $\mathrm{KGH}$ sebagai media pembelajaran dapat meningkatkan kemampuan membaca peserta didik sehingga sekolah perlu menyediakan APE KGH lebih banyak agar anak-anak tidak berebut ketika belajar menggunakan alat ini.

4. Bagi pengembang lain, penelitian ini terbatas pada dua sekolah sehinga perlu penelitian lanjutan dengan menggunakan sampel yang lebih luas di samping media yang dikembangkan masih bersifat sederhana sehingga perlu pula memikirkan pengembangan lebih luas agar dapat digunakan sebagai alat bantu belajar membaca lebih cepat dan menyenangkan.

\section{DAFTAR PUSTAKA}

Evangelou, D. et al. (2010). Talking about Artifacts: Preschool Children's Explorations with Sketches, Stories, and Tangible Objects. Early Childhood Research \& Practice, 12(2), 1-10

Hasan, M. (2009). PAUD (Pendidikan Anak Usia Dini). Yogjakarta: Diva Press.

Sujiono, Y. N \& Sujiono, B. (2013). Bermain Kreatif Berbasis Kecerdasan Jamak. Jakarta: PT Indeks.

Eggen, P. \& Kauchak, D. (2012). Strategi dan Model Pembelajaran Mengajarkan Konten dan Ketrampilan Berpikir. Jakarta: PT Indeks.

Kabuto, B. (2009). Color as a Semiotic Resource in Early Sign-Making. Early Childhood Research \& Practice, 11(2) 1-18

Wang, C., Christ, T. \& Chiu, M. M. (2013). Exploring a Comprehensive Model for Early Childhood Vocabulary Instruction: a Design Experiment. Early Child Development and Care, 184(7), 1-32 